\section{Amplification of RNA}

\section{Ayoub Rashtchian}

Life Technologies, Inc., Department of Molecular Biology, Gaithersburg, Maryland 20884
PCR has been used widely to study gene expression by amplification from RNA sequences. This approach requires conversion of the mRNA template to CDNA by reverse transcription (RT) and amplification of the CDNA by PCR (RNA PCR or RT-PCR). ${ }^{(1,2)}$ RT-PCR is now a major methodology for detecting the expression of genes. This method is particularly useful when analyzing low-abundance mRNAs or when a limited amount of sample is available. Also, RT-PCR been used widely as a qualitative and a quantitative tool for studying the expression of genes and for the detection of viral RNAs. ${ }^{(3-5)}$ Amplification of RNA and cloning of amplified DNA also provide a convenient alternative to conventional cDNA cloning. A wide variety of modifications have been applied to the original RT-PCR method, depending on the purpose(s) of the study. Also, a number of different reverse transcriptases have been used to convert the RNA into CDNA prior to amplification by PCR. The basic methology for RT-PCR is shown schematically in Figure 1. This paper deals with a number of different methods involving RT-PCR. A general protocol and a discussion of factors to consider in using RT-PCR for detection and quantitation of RNA in biological samples are presented.

\section{QUALITY OF THE RNA}

Successful cDNA synthesis begins with the isolation of high-quality RNA. One of the most important factors preceding the synthesis of cDNA is the isolation of intact RNA. Because quality of the RNA dictates the maximum amount of sequence information that can be converted into cDNA, it is important to optimize the isolation of RNA from a given biological source ${ }^{(6)}$ and to prevent adventitious introduction of RNases into the RNA preparation or other reagents. RNA can be isolated for use in RT-PCR by many methods. The guanidine isothiocyanate/acid-phenol method described by Chomczynski and Sacchi, ${ }^{(7)}$ which yields nondegraded RNA from cultured cells or whole tissue samples, has been used extensively. The TrizOL Reagent (Life Technologies; GIBCO BRL, Gaithersburg, MD; catalog no. 15596-018) method, which is an improvement of the original single-step method of Chomczynski and Sacchi, can also be used. ${ }^{(7,8)}$ The amount of starting material for the preparation of RNA may be varied from $1 \times 10^{7}$ cells to as little as $1 \times 10^{3}$ cells, which is advantageous in applications where only small amounts of cellular material are available. ${ }^{(9-11)}$

The guanidine isothiocyanate-based lysis procedure originally developed by Chirgwin et al., ${ }^{(12)}$ and later modified and refined ${ }^{(6,13)}$ can also be used. For the isolation of RNA from small quantities of sample $\left(<10^{6}\right.$ cells or $<10$ mg of tissue), the GlassMAX RNA Microisolation Spin Cartridge System is recommended. ${ }^{(14)}$

Typically, oligo(dT) selection for poly(A) ${ }^{+}$RNA is not necessary, although incorporating this step may improve the yield of specific cDNAs and thus simplify subsequent amplification steps. Oligo(dT) selection is more useful in cloning applications of RT-PCR. Poly(A) ${ }^{+}$RNA selection may also reduce the likelihood of genomic DNA contamination, which is undesirable when studying the expression of genes.

Frequently, RNA preparations contain small amounts of genomic DNA that subsequently may be amplified along with the target cDNA. Some applications may require removal of all genomic DNA from the RNA preparation, and this can be accomplished by DNase I digestion of the RNA preparation. This step is especially important when amplifying mRNAs from intronless genes and when the amplification region is contained within a single exon (see Selective Amplification of RNA in the presence of DNA, below).

\section{PROCEDURE FOR REMOVAL OF DNA IN RNA PREPARATIONS}

The trace amounts of DNA often present in RNA preparations can be removed 

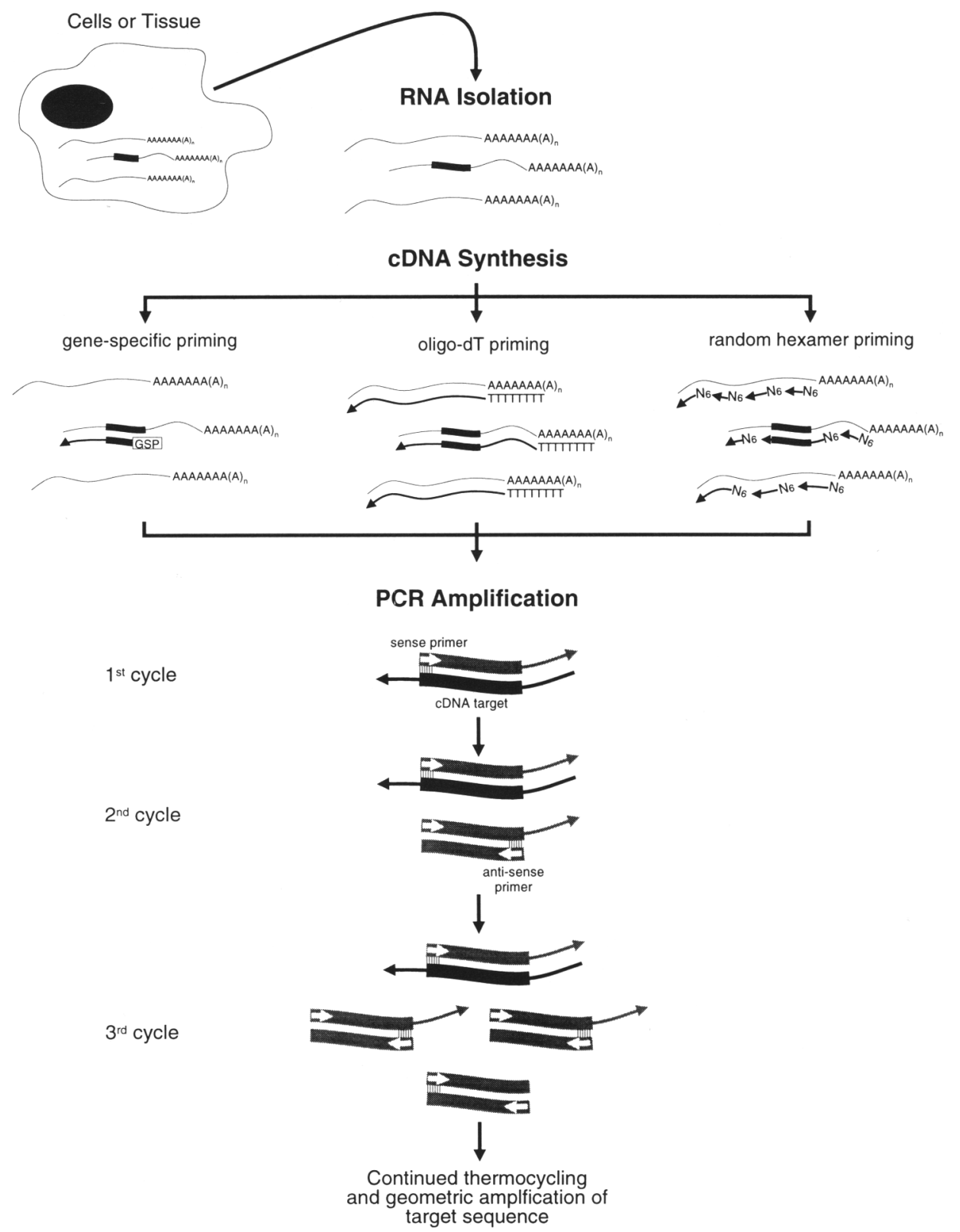

FIGURE 1 Schematic representation of various methods for amplification of RNA by PCR.

using amplification-grade DNase I. The following protocol is recommended for treatment of $1 \mu \mathrm{g}$ of RNA.

1. Add $1 \mu \mathrm{g}$ of RNA to an RNase-free $0.5-\mathrm{ml}$ microcentrifuge tube and place on ice.

2. Add $1 \mu$ l of $10 \times$ DNase I reaction buffer [ $200 \mathrm{~mm}$ Tris- $\mathrm{HCl}(\mathrm{pH} 8.4), 500$ $\mathrm{mm} \mathrm{KCl}, 25 \mathrm{~mm} \mathrm{MgCl}_{2}, 1 \mathrm{mg} / \mathrm{ml} \mathrm{BSA}$ ].

3. Add 1 unit of amplification-grade DNase I (GIBCO/BRL catalog \#18068015).

4. Bring the volume to $10 \mu \mathrm{l}$ with DEPC-treated distilled water and incubate at room temperature for $15 \mathrm{~min}$.

5. Inactivate the DNase I by adding $1 \mu \mathrm{l}$ of $20 \mathrm{~mm}$ EDTA to the reaction mixture and heating for $10 \mathrm{~min}$ at $65^{\circ} \mathrm{C}$. The DNase I-treated RNA can be used directly for RT. 


\section{CHOICE OF REVERSE TRANSCRIPTASE}

A variety of reverse transcriptases are available for synthesis of cDNA prior to RT-PCR. These enzymes include MMLV RT, AMV RT, and thermostable reverse transcriptase from Thermus thermophilus. There are also two RNase $\mathrm{H}^{-}$ mutants of MMLV RT, which are marketed as SuperScript and SuperScript II. All of these enzymes have been used successfully in RT-PCR. Because the first step in RT-PCR involves reverse transcription of RNA into DNA, maximum conversion of RNA into DNA is of critical importance to the success of RTPCR. Depending on the purpose and design of the RT-PCR, the requirement for synthesis of full-length cDNA varies. For cloning applications, it is generally better if the cDNA is full length. This is also true if the region of target to be amplified is near the $5^{\prime}$ end of mRNA. The RNase $\mathrm{H}^{-}$derivatives of MMLV RT can convert a greater proportion of the RNA into cDNA and can synthesize longer cDNAs than other enzymes, because of a lack of RNase $\mathrm{H}$ activity. ${ }^{(15,16)}$ These enzymes also operate at a higher temperature $\left(50^{\circ} \mathrm{C}\right)$ than their wild-type counterparts and AMV RT. This property allows synthesis of longer cDNAs from mRNA templates with secondary structure that are difficult to copy at lower temperatures. Gerard et al. ${ }^{(16)}$ have compared the cDNA yield from a 7.5-kb mRNA using different enzymes and have demonstrated that use of SuperScript II resulted in 2.5 times more cDNA when compared with other enzymes.

The DNA polymerase from the thermophilic eubacterium Thermus thermophilus (Tth polymerase) exhibits a reverse transcriptase activity in the presence of $\mathrm{Mn}^{2+} .{ }^{17)}$ The thermophilic nature of this enzyme allows RT of RNA at high temperatures, which alleviates secondary structures present in the RNA template. More recently, Bicine buffer has been used to develop a onestep RT-PCR method that utilizes the $T$ th polymerase as reverse transcriptase as well as DNA polymerase for amplification. ${ }^{(18)}$ One of the limitations of using thermostable reverse transcriptase is that it is not suitable for use with oligo(dT) or short random primers (see below).

\section{CHOICE OF PRIMER FOR CDNA SYNTHESIS}

Choice of primer for CDNA synthesis is largely dictated by specific application of the RT-PCR. A first-strand CDNA synthesis reaction may be primed using three different methods (Fig. 1). The relative specificity of each primer for RNA influences the amount and variety of cDNA synthesized.

1. The most nonspecific of the primers, random hexamers, are typically used when a particular mRNA is difficult to copy in its entirety, because of the presence of sequences that cause the RT to abort synthesis. ${ }^{(19,20)}$ With this method, all RNAs in a population are templates for first strand cDNA synthesis, and the PCR primers confer the needed specificity during the PCR amplification reaction. Generally $96 \%$ of all cDNA synthesized using random hexamers is from rRNA. To maximize the size of cDNA synthesized using random hexamers, the ratio of primers to RNA may need to be determined empirically for each RNA preparation.

2. A method specific for mRNA is to use oligo(dT) as the primer. When the primer is hybridized to $3^{\prime}$ poly(A) tails, which are found in the vast majority of eukaryotic mRNAs, ${ }^{(21)}$ only the mRNA is transcribed. Because poly(A) ${ }^{+}$ RNA constitutes $\sim 1-2 \%$ of a total RNA population, the amount and complexity of cDNA is considerably less than when random hexamers are used. Because of its high specificity, oligo(dT) priming generally does not require optimization of the primer/RNA ratio.

3. The most specific of the priming methods is to use an oligonucleotide containing sequence information complementary to the target RNA. If the PCR amplification reaction uses two specific primers, first-strand synthesis 


\section{Manual Supplement IIIII}

can be primed with the amplification primer that hybridizes nearest to the $3^{\prime}$ terminus of the mRNA. The advantage of using a specific primer is that the specific cDNA is produced, resulting in a more specific PCR amplification. In addition, regardless of the location of the amplification target in the mRNA, the cDNA represents the amplification region.

\section{PROTOCOL}

The following protocol has been adapted from the Superscript II Preamplification system (Life Technologies; GIBCO BRL, Gaithersburg, MD; catalog no. 18089-011) for amplification of RNA. The protocol is intended to be a general protocol for conversion of RNA into cDNA and amplification of the cDNA by PCR.

\section{First-strand CDNA Synthesis}

This procedure is designed to convert $1-5 \mu \mathrm{g}$ of total RNA into first-strand cDNA. The protocol has been optimized for this amount of starting RNA and should be followed for best results.

1. Add $1-5 \mu \mathrm{g}$ of total RNA in $13 \mu \mathrm{l}$ of DEPC-treated water to an autoclaved 0.5-ml microcentrifuge tube.

2. Add $1 \mu \mathrm{l}$ of either oligo(dT) $(0.5 \mathrm{mg} / \mathrm{ml})$ or random hexamer solution $(50 \mathrm{ng} / \mu \mathrm{l})$ to the tube and mix gently.

3. Heat the mixture to $70^{\circ} \mathrm{C}$ for $10 \mathrm{~min}$ and incubate on ice for $1 \mathrm{~min}$. Collect the contents of the tube by brief centrifugation and add the following:

\begin{tabular}{lc} 
Component & $\begin{array}{c}\text { Volume } \\
(\mu \mathrm{l})\end{array}$ \\
\hline $10 \times$ synthesis buffer [200 mM Tris- $\mathrm{HCl}(\mathrm{pH}$ & \\
$8.4), 500 \mathrm{mM} \mathrm{KCl}, 25 \mathrm{mM} \mathrm{MgCl}{ }_{2}, 1 \mathrm{mg} / \mathrm{ml}$ & 2 \\
of BSA] & 1 \\
$10 \mathrm{mM}$ dNTP mix $(10 \mathrm{~mm}$ each) & 2 \\
$0.1 \mathrm{M}$ DTT & 1 \\
SuperScript II RT $(200 \mathrm{U} / \mu \mathrm{l})$ &
\end{tabular}

4. Mix gently and collect the reaction by brief centrifugation. Incubate at room temperature for $10 \mathrm{~min}$.

5. Transfer the tube to a $42^{\circ} \mathrm{C}$ water bath or heat block and incubate for 50 $\min$.

6. Terminate the reaction by incubating the tube at $70^{\circ} \mathrm{C}$ for $15 \mathrm{~min}$. Place on ice.

7. Collect the reaction by brief centrifugation. Add $1 \mu$ l of RNase H ( 2 units) to the tube and incubate for $20 \mathrm{~min}$ at $37^{\circ} \mathrm{C}$ before proceeding to PCR amplification.

\section{Amplification of the Target CDNA}

The first-strand cDNA obtained using the above protocol may be amplified directly by PCR. Although the whole cDNA mixture can be amplified, often a small amount of the cDNA $(2-3 \mu \mathrm{l})$ is sufficient for most purposes. If the cDNA has been prepared by oligo(dT) or the random primer method, the same cDNA can be used for many amplifications using different amplification primers.

1. Add the following to the first-strand reaction tube: 


\begin{tabular}{lc} 
Component & $\begin{array}{c}\text { Volume } \\
(\mu \mathrm{l})\end{array}$ \\
\hline 10× synthesis buffer & 8 \\
Autoclaved, distilled water (adjust if using & 68 \\
$\quad$ only part of cDNA) & 1 \\
Amplification primer $1(10 \mu \mathrm{M})$ & 1 \\
Amplification primer $2(10 \mu \mathrm{M})$ & 1 \\
Taq DNA polymerase $(2-5 \mathrm{U} / \mu \mathrm{l})$ &
\end{tabular}

2. Mix gently and layer 2 drops $(\sim 100 \mu \mathrm{l})$ of mineral oil over the reaction.

3 . Heat the reaction mixture to $94^{\circ} \mathrm{C}$ for $5 \mathrm{~min}$ to denature any $\mathrm{RNA} / \mathrm{cDNA}$ hybrid that may have escaped RNase $\mathrm{H}$ digestion.

4. Perform 15-30 cycles of PCR amplification:

$\begin{array}{ll}\text { Denature } & 94^{\circ} \mathrm{C} \text { for } 1 \mathrm{~min} \\ \text { Anneal } & 55^{\circ} \mathrm{C} \text { for } 30 \mathrm{sec} \\ \text { Extend } & 72^{\circ} \mathrm{C} \text { for } 2 \mathrm{~min}\end{array}$

5. Analyze 10-20 $\mu \mathrm{l}$ of the amplified sample using agarose gel electrophoresis and the appropriate molecular size standards. If the positive control RNA from the kit is used, a single 523-bp band will be visible. It should be noted that as with any PCR the optimum conditions for amplification are dependent on the particular sequence being amplified, primers used, and the optimum $\mathrm{Mg}^{2+}$ concentration. The protocol given above is a general protocol that is applicable to many cases. However, the cycling parameters and $\mathrm{Mg}^{2+}$ concentration should be optimized for each individual case.

\section{Selective Amplification of RNA in the Presence of DNA}

To study the expression of genes, it is important to amplify cDNA selectively from mRNA rather than genomic DNA. Frequently, RNA preparations contain small amounts of DNA that may subsequently be amplified along with the target cDNA. A number of approaches have been used to differentiate between amplification from RNA and amplification from DNA. The most common method is to pretreat the RNA with an RNase-free DNase (amplification grade DNase I, catalog no. 18068-015, Life Technologies; GIBCO BRL, Gaithersburg, MD) prior to RT-PCR. Inclusion of a control reaction without RT to determine whether the amplification product is of genomic DNA or of cDNA origin is also recommended.

Another common method for differentiating between RNA and DNA employs primers that span the splice junctions in the RNA. This method is restricted to those RNA species that are spliced and imposes strict limitations on the design of amplification primers. The technique also requires substantial sequence information and knowledge of intron/exon boundaries. It is also possible to design primers that span an intron, resulting in different size amplification products from spliced RNA and the genomic DNA with intron. However, this approach is limited to genes with introns and is not applicable to all genes, the bacterial transcripts, or the processed pseudogenes. ${ }^{(22)}$

Using a different method, Moore and co-workers ${ }^{(23)}$ have designed primers to the junction of $3^{\prime}$-untranslated sequence and the poly(A) tract. Although this method is generally applicable, it requires the 3 '-untranslated sequence of the mRNA to be known and limits amplification to the $3^{\prime}$ region of the mRNA. In addition, this approach is often problematic because of shared sequences in the 3'-untranslated region of many mRNAs. Recently, we have described a method for selective amplification of RNA in samples that may contain DNA of the same sequence [Fig. $2^{(24)}$ ]. The method utilizes a dU- 


\section{Manual Supplement IIIIII}

A

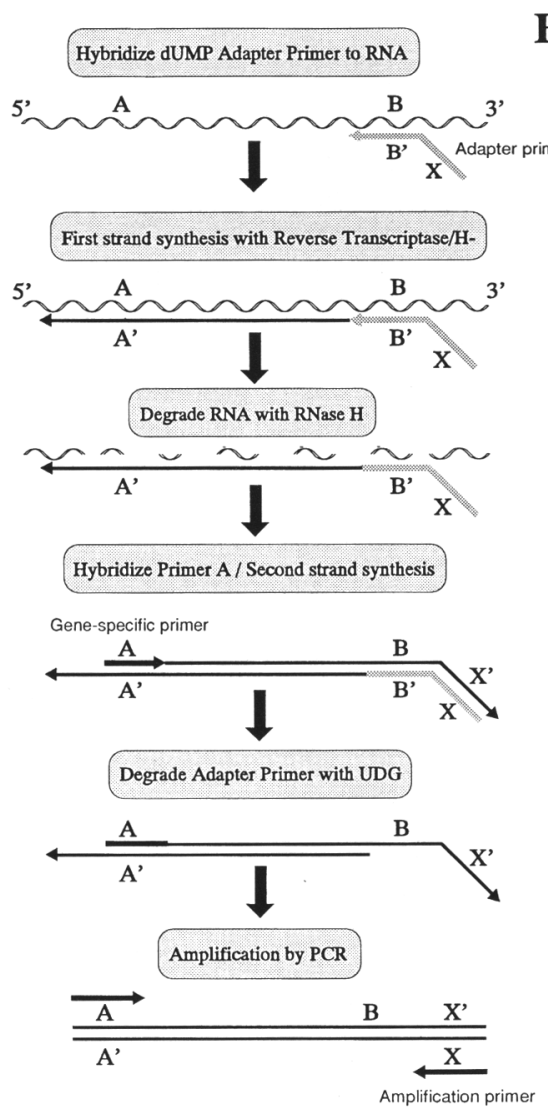

B

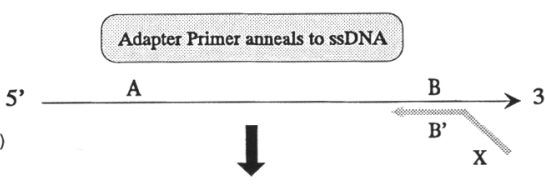

Primer extension using Reverse Transcriptase/H-

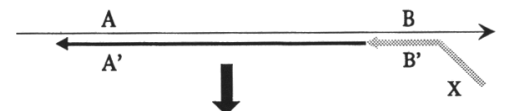

Treat with RNase

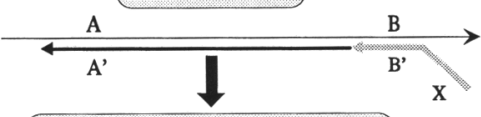

Add Primer A / No Second Strand Synthesis
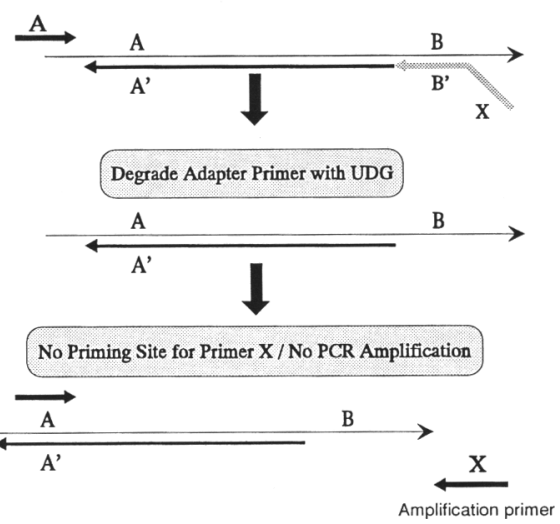

FIGURE 2 Schematic depiction of the strategy used for selective amplification of RNA by PCR. ${ }^{(23)}$ $(A)$ Application of the method to RNA; $(B)$ the failure of second-strand DNA to amplify. The sequence of the oligonucleotide primer used here is 5'-GGG AGA CCG GAA UUC UCC UUC AAU UGC UGA UGC AGG UGA C-3'.

containing oligonucleotide as an adaptor primer for first-strand synthesis on RNA. This primer contains a unique "adaptor" nucleotide sequence at its 5' end that is not found in either the DNA or RNA. The introduction of new sequences into cDNA generated from RNA and not DNA allows selective amplification of RNA. After RT copies the sequence into the second-strand cDNA, the original adaptor primer is destroyed using uracil DNA glycosylase. The method is applicable to any RNA and permits amplification of any userdefined region within the RNA molecule.

\section{Quantitative RT-PCR}

PCR amplification of RNA has been used widely not only as a qualitative technique but also as a quantitative or semiquantitative approach for detection of various mRNAs. Relative quantitation of mRNA has been used to study temporal and differential expression, ${ }^{(1,25-27)}$ to quantitate allele-specific transcripts differing by a single nucleotide, ${ }^{(28)}$ or to detect HIV-1 in various stages of infection. ${ }^{(4)}$ Two general types of internal standards have been used for quantitative RT-PCR: (1) endogenous standard; and (2) exogenous standard.

An endogenous standard generally is known to be present at constant levels in the samples to be analyzed, and this serves as the quantitation standard. mRNA for housekeeping genes has been used as an internal standard to determine relative levels of a specific mRNA [reviewed in Manual Supplement Section 2, pp. S123-S135 (PCR Methods Applic., Vol. 3, no. 6) by Gause and Adamovicz]. ${ }^{(29-31)}$ Alternatively, single-copy gene sequences have been utilized as internal DNA standards for quantitation of DNA. When using 
an endogenous standard, a second pair of standard-specific primers is used in addition to the primers used for amplification of the target RNA. The PCR reactions for the standard and the sample target can be performed separately or they can be combined as a multiplex reaction. The quantitation is achieved by comparison of the ratios of the amount of PCR products between the standard and the sample. In this procedure it is very important to analyze the reactions before amplification reaches the plateau phase.

The significant advantage of the internal standard method for RNA is the fact that the standard mRNA and sample mRNA are purified together. Coprocessing of standard and sample RNA minimizes the artifacts, such as differences in RNA yields, accurate quantitation, and cDNA synthesis in steps prior to PCR amplification.

One of the disadvantages of using an endogenous internal standard is that the concentration of the standard might be greatly different than that of the target mRNA. This makes quantitation difficult because the RNA with the higher concentration reaches the plateau phase sooner than the target RNA. It should be noted also that while amplification of the standard and target RNA in the same tube eliminates tube-to-tube variability, the primers can interfere with each other (i.e., primer-dimer formation) and result in lower overall amplification. Another factor to consider when using an endogenous internal RNA standard is the choice of priming sites within the RNA. If the segment of RNA to be amplified using this method is close to the $5^{\prime}$ end of mRNA in one RNA but not the other, inefficiencies in the full-length cDNA synthesis will result in biased quantitation. However, use of a reverse transcriptase that is efficient in synthesis of long cDNA, such as $\mathrm{RNase}^{-} \mathrm{Su}$ perscript RT, or use of random primers for CDNA synthesis, would alleviate this problem.

The second class of standards for the quantitative PCR is the use of an exogenous sequence. In this approach an exogenous RNA is added to the sample and is amplified simultaneously with target mRNA in the same tube. The advantage of the exogenous standards is that the amount of RNA added to the sample is known precisely and can be varied to match the concentration of the target mRNA in the sample. A modification of the exogenous standard method is to construct an RNA that is identical to the target RNA, except for a deletion or an insertion, resulting in an amplification product slightly smaller or larger than the product from target RNA. This allows use of the same primers for the standard as well as the target RNA and eliminates differences in the priming efficiency that would be caused by use of multiple set of primers.

$A$ variation in the use of exogenous standard is quantitative competitive PCR (QC PCR). ${ }^{(3)}$ In this method, a competitive RNA template matched to the target RNA but differing in size, because of a deletion, is used in a competitive titration of the RT and PCR steps. Increasing known copy numbers of the exogenous competitive standard are added to replicate reactions containing target RNA and amplified by RT-PCR. Determination of the relative amounts of the amplification products corresponding to the target RNA and the standard RNA allows quantitation of the target RNA in the test sample.

\section{ADDITIONAL APPLICATIONS AND SUMMARY}

In addition to the applications discussed above, RT-PCR has served as a basic tool for analyzing RNA in a variety of biological systems. RT-PCR with singlesided specificity has been used to amplify and clone rare mRNAs. ${ }^{(21,32,33)}$ This procedure, which has been termed "RACE" (rapid amplification of $\underline{\text { cDNA }}$ ends), has been used extensively to amplify the $3^{\prime}$ or $5^{\prime}$ ' ends of the mRNA. The $3^{\prime}$ RACE method takes advantage of the $3^{\prime}$ poly(A) sequence of mRNA and 
amplifies the $3^{\prime}$ ends using a combination of a gene-specific primer and an anchor primer, which anneals to the homopolymeric tail. In the 5' RACE method, a homopolymeric tail is added to the $3^{\prime}$ end of the first-strand cDNA (which corresponds to the $5^{\prime}$ end of mRNA) and in turn is amplified in combination with a gene-specific primer.

The $5^{\prime}$ RACE method is especially powerful because it reveals the $5^{\prime}$ ends of mRNA, which are often inaccessible through traditional cDNA library methods. A similar but distinct strategy of amplification of mRNA has been used to construct PCR-amplified cDNA libraries. ${ }^{(34)}$ Applications of these technologies hold the promise of making cell type-specific cDNA libraries and of studying the genes functioning in a single cell. Other significant uses of RT-PCR are differential display analysis of differentially expressed genes ${ }^{(35)}$ and in situ analysis of gene expression in individual cells through in situ RT-PCR. ${ }^{(36,37)}$

\section{ACKNOWLEDGMENTS}

I would like to thank David Schuster for useful discussions and Dominica Simms for providing the protocol for DNase I digestion.

\section{REFERENCES}

1. Rappolee, D.A., D. Mark, M.J. Baanda, and Z. Werb. 1988. Wound macrophages express TGF-alpha and other growth factors in vivo: Analysis by mRNA phenotyping. Science 241: 708-710.

2. Kawasaki, E.S. and A.M. Wang. 1989. Detection of gene expression. In PCR technology, principles, and applications for DNA amplification (ed. H.A. Erlich), pp. 89-97. Stockton Press, New York.

3. Singer-Sam, J., M.O. Robinson, A.R. Bellve, M.I. Simon, and A. Riggs. 1990. Measurement by quantitative PCR of changes in HPRT, PGK-1, PGK-2, APRT, MTase, and Zfy gene transcripts during mouse spermatogenesis. Nucleic Acids Res. 18: 1255-1259.

4. Piattak, M., M.S. Saag, L.C. Yang, S.J. Clark, J.C. Kappes, K.-C. Luk, B.H. Hahn, G.M. Shaw, and J.D. Lifson. 1993. High levels of HIV-1 in plasma during all stages of infection determined by competitive PCR. Science 259: 1749-1754.

5. Wang, M., M.V. Doyle, and D.F. Mark. 1989. Quantitation of mRNA by polymerse chain reaction. Proc. Natl. Acad. Sci. 86: 9717-9721.

6. Sambrook J., E.F. Fritsch, and T. Maniatis. 1989. Molecular cloning: A laboratory manual. Cold Spring Harbor Laboratory Press, Cold Spring Harbor, New York.

7. Chomczynski, P. and N. Sacchi. 1987. Single-step method of RNA isolation by acid guanidium thiocyanate-phenol-chloroform extraction. Anal. Biochem. 162: 156-159.

8. Chomczynski, P. 1993. A reagent for the single-step simultaneous isolation of RNA, DNA and proteins from cell and tissue samples. Biotechniques 15: 532-535.

9. Chelly, J., J. Kaplan, P. Maire, S. Gautron, and A. Kahn. 1988. Transcription of dystrophin gene in human muscle and non-muscle tisues. Nature 333: 858-860.

10. Rappolee, D.A., A. Wang, M.J. Banda, and Z. Werb. 1989. Novel method for studying mRNA phenotypes in single or small number of cells. J. Cell. Biochem. 39: 1-11.

11. Berchtold, M.W. 1989. A simple method for direct cloning and sequencing of cDNA by the use of a sinqle oligonucleotide and oligo(dT) in a polymerase chain reaction. Nucleic Acids Res. 17: 453.

12. Chirgwin, J.M., A.E. Przybyla, R.J. MacDonald, and W.J. Rutter. 1979. Isolation of biologically active ribonucleic acid from sources enriched in ribonuclease. Biochemistry 18: 5294-5299.

13. Han, J.H., C. Stratowa, and W.J. Rutter. 1987. Isolation of full length putative rat lysophospholipase cDNA using improved methods for mRNA isolation and cDNA cloning. Biochemistry 26: 1617-1625.

14. Simms, D. 1993. Rapid micro-scale isolation of RNA for PCR or translation. Focus 15: 6-11.

15. Kotewicz, M.L., C.M. Sampson, J.M. D'Alessio, and G.F. Gerard. 1988. Isolation of cloned Moloney murine leukemia virus reverse transcriptase lacking ribonuclease $\mathrm{H}$ activity. Nucleic Acids Res. 16: 265-277.

16. Gerard, G.F., B.J. Schmidt, M.L. Kotewicz, and J.H. Campbell. 1992. cDNA synthesis by Moloney murine leukemia virus RNase $\mathrm{H}$-minus reverse transcriptase possessing full DNA polymerase activity. Focus 14: 91.

17. Meyers, T.W. and D.H. Gelfand. 1991. Reverse transcription and DNA amplification by a Thermus thermophilus DNA polymerase. Biochemistry 30: 7661-7666.

18. Meyers, T.W., C.L. Sigua, and D.H. Gelfand. 1994. High temperature reverse transcription 
and PCR by a Thermus thermophilus DNA polymerase. Proceedings of the 1994 Miami Bio/ Technology Winter Symposium. Advances in gene technology: Molecular biology and human disease, p. 87.

19. Compton, T. 1990. In PCR protocols: $A$ guide to methods and applications (ed. M. Innis, D. Gelfand, J. Sninsky, and T. White), p. 39. Academic Press, Inc., San Diego, CA.

20. Lee, C.C. and T. Caskey. 1990. In PCR protocols: A guide to methods and applications (ed. M. Innis, D. Gelfand, J. Sninsky, and T. White), p. 46. Academic Press, Inc., San Diego, CA.

21. Frohman, M.A., M.K. Dush, and G.R. Martin. 1988. Rapid production of full-length cDNAs from rare transcripts: Amplification using a single gene-specific oligonucleotide primer. Proc. Natl. Acad. Sci. 85: 89-98.

22. Menon, R.S., Y. Chang, J. St. Clair, and R.G. Ham. 1991. RT-PCR artifacts from processed pseudogenes. PCR Methods Applic. 1: 70-71.

23. Moore, R.E., J.W. Shepherd, and J. Hoskins. 1991. Design of PCR primers that detect only mRNA in the presence of DNA. Nucleic Acids Res. 18: 1921.

24. Buchman, G.W., D.M. Schuster, and A. Rashtchian. 1993. Selective RNA amplification: A novel method using dUMP-containing primers and uracil DNA glycosylase. PCR Methods Applic. 3: 28-31.

25. Arrigo, S.J., S. Weitman, J.A. Zack, and I.S.Y. Chen. 1990. Characterization and expression of novel singly spliced RNA species of human immunodeficiency virus type 1. J. Virol. 64: $4585-4588$.

26. Neve, R.L., J. Rogers, and G.A. Higgins. 1990. The Alzheimer amyloid precursor-related transcript lacking the Beta/A4 sequence is specifically increased in Alzheimer's disease brain. Neuron 5: 329-338.

27. Ferre, F., A. Marchese, P. Pezzoli, S. Griffin, E. Buxton, and V. Boyer. 1994. Quantitative PCR: An overview. In The polymerase chain reaction (ed. K.B. Mullis, F. Ferre, and R.A. Gibbs), Birkhauser, Boston, MA.

28. Singer-Sam, J., J.M. LeBon, A. Dai, and A.D. Riggs. 1992. A sensitive, quantitative assay for measurement of allele-specific transcripts differing by a single nucleotide. PCR Methods Applic. 1: $160-163$.

29. Sivitz, W.I. and E.C. Lee. 1991. Assessment of glucose transporter gene expression using the polymerase chain reaction. Endocrinology 128: 2387-2394.

30. Murphy, L.D., C.E. Herzog, J.B. Rudik, A.T. Fojo, and S.E. Bates. 1990. Use of polymerase chain reaction in the quantitation of mdr-1 gene expression. Biochemistry 29: 10351-10356.

31. Kinoshita, T., J. Imamura, H. Nagai, and K. Shimotohno. 1992. Quantification of gene expression over a wide range by the polymerase chain reaction. Anal. Biochem. 206: 231-235.

32. Schuster, D., G. Buchman, and A. Rashtchian. 1992. A simple and efficient method for amplification of cDNA ends using 5' RACE. Focus 14: 46-52.

33. Buchman, G.W. and A. Rashtchian. 1992. PCR amplification of nucleic acid sequences using the 3' RACE system and direct cloning of the amplified products. Focus 14: 2-5.

34. Gurr, S.J. and M.J. McPhearson. 1993. PCR-directed cDNA libraries. In PCR: A practical approach (ed. M.J. McPhearson, P. Quirk, and G.R. Taylor), pp. 147-170. IRL Press, Oxford, UK.

35. Liang, P. and A. Pardee. 1992. Differential display of eucaryotic mRNA by means of the polymerase chain reaction. Science 257: 967-971.

36. Bagasra, O., S.P. Hauptman, H.W. Lischner, M. Sachs, and R.J. Pomerantz. 1992. Detection of HIV-1 provirus in mononuclear cells by in situ PCR. N. Engl. J. Med. 326: 1385-1391.

37. Nuovo, G.J., G.A. Gorgone, P. MacConnel, M. Margiota, and P.D. Gorevic. 1993. In situ localization of PCR-amplified human and viral cDNAs. PCR Methods Applic. 2: 117-123. 


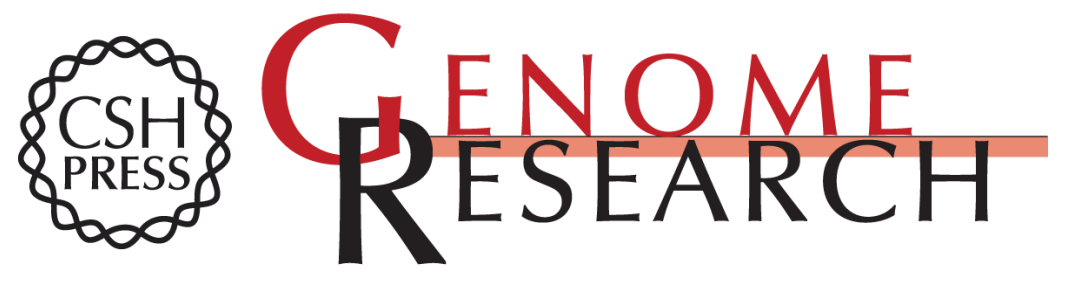

\section{Amplification of RNA.}

A Rashtchian

Genome Res. 1994 4: S83-S91

References This article cites 30 articles, 5 of which can be accessed free at: http://genome.cshlp.org/content/4/2/S83.full.html\#ref-list-1

\section{License}

Email Alerting Receive free email alerts when new articles cite this article - sign up in the box at the Service top right corner of the article or click here.

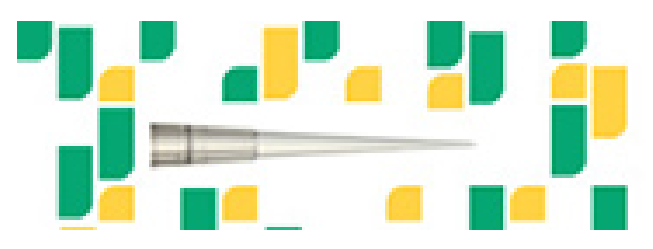

To subscribe to Genome Research go to: https://genome.cshlp.org/subscriptions 